УДК 552.578.3

ISSN 1609-0691

DOI: https://doi.org/10.17308/geology.2021.1/3335

Поступила в редакцию: 15.02.2021

Принята к публикации: 01.03.2021

Опубликована онлайн: 31.03.2021

\title{
Верхнеюрские горючие сланцы Волжского бассейна: литотипы, модели формирования, продуктивность
}

\author{
(С2021 В. С. Илясов ${ }^{1 凶}$, В. Н. Староверов ${ }^{2}$ \\ ${ }^{1}$ ООО «НьюТек Сервисез», ул. Шаболовская 31Г, 115162, Москва, Российская Федерация \\ ${ }^{2}$ Нижневолжский научно-исследовательский институт геологии и геофизики, \\ ул. Московская 70, 413503, Саратов, Российская Федерация
}

\begin{abstract}
Аннотация
Введение: Продуктивность горючих сланцев Коцебинского и Перелюбского месторождения сильно изменяется как по вертикали, так и по латерали. Данная статья посвящена изучению влияния изменчивости условий формирования на продуктивность горючих сланцев Волжского бассейна.

Методика и фактический материал: В работе использованы следующие методы: макроописание керна, литолого-петрографические исследования шлифов и изучение электронномикроскопических снимков. При анализе условий формирования горючих сланцев использовался материал, полученный в процессе выполнения поисково-оценочных и разведочных работ на Коцебинском и Перелюбском месторождениях.

Результаты и обсуждения: На основании изучения основных литотипов горючих сланцев Коцебинского и Перелюбского месторождений были установлены процессы, влияющие на продуктивность горючих сланцев: объем поступления терригенного материала, биопродуктивность палеобассейна и степень фоссилизации органического вещества (OB).

Заключение: Установлено, что низкая продуктивность горючих сланцев обусловлена высокой интенсивностью поступления терригенного материала с источников сноса, а также низкой степенью фоссилизации ОВ. Тогда как рост продуктивности горючих сланцев связан с низкой интенсивностью поступления терригенного материала и высокой степенью фоссилизации ОВ. Для двух литотипов предполагается высокая биопродуктивность палеобасссейна. Полученные данные позволили построить и рассмотреть вероятные «идеализированные» модели формирования горючих сланцев. В дальнейшем эти данные могут быть использованы для реконструкции условий образования каждого продуктивного пласта горючих сланцев.

Ключевые слова: горючие сланцы, Волжский бассейн, продуктивность, Коцебинское месторождение, аноксические условия, вулканизм.

Для цитирования: Илясов В.С., Староверов В.Н. Верхнеюрские горючие сланцы Волжского бассейна: литотипы, модели формирования, продуктивность // Вестник Воронежского государственного университета. Серия: Геология. 2021. №1. С. 26-35. DOI: https://doi.org/10.17308/geology.2021.1/3335.
\end{abstract}

\section{Введение}

Южный сектор Волжского бассейна располагается на юго-востоке Русской плиты и приурочен к переходной области от Волго-Уральской антеклизы к прибортовой зоне Прикаспийской впадины.
Горючие сланцы приурочены к аммонитовой зоне Dorsoplanites panderi средневолжского подъяруса волжского яруса верхней юры $[1,2]$.

На территории Саратовской области выделяются шесть месторождений горючих сланцев: Орловское,

Контент доступен под лицензией Creative Commons Attribution 4.0 License.

\footnotetext{
凶 Илясов Валерий Сергеевич, e-mail: 230989@1ist.ru
} 
Савельевское, Озинковское, Перелюбское, Коцебинское и Кашпир-Хвалынская площадь. Сланценосная толща представлена переслаиванием глинисто-карбонатных отложений с пластами горючих сланцев. Количество продуктивных пластов колеблется от 3 до 9 даже на территории одного месторождения, а их мощность варьирует от 0.5 до 1 м. Мощность толщи в целом изменяется от 10 до 100 м и достигает максимальных величин на Перелюбском месторождении [3].

Кроме сланцевого газа из них могут быть получены сланцевая нефть, дорожный битум и пр. Также за последние два года появились новые данные о высоких содержаниях рения, золота, серебра и платины в Волжских горючих сланцах [4]. В настоящее время для перехода на стадию разведки рассматриваемого вида сырья остро необходима всеобъемлющая литологическая характеристика горючих сланцев (ГС) и адекватная седиментационная модель их формирования. Не менее актуальной является проблема изучения, и не только для рассматриваемого региона, влияния вещественного состава сланцев на их технологические характеристики.

При детальном изучении качества ГС Перелюбского и Коцебинского месторождений рассматривались следующие основные параметры: мощность продуктивного пласта (м), теплота сгорания (ккал/кг), выход жидких углеводородов в процессе пиролиза на единицу объема породы (\%), зольность, содержание минеральной составляющей в единице объема горючего сланца после пиролиза (\%), содержание серы (\%) [5]. При этом, авторы статьи исходят из постулата, что данные параметры характеризуют не только качество горючего сланца, но и отражают условия осадконакопления для каждого продуктивного пласта. Значительные колебания этих параметров отмечаются и в вертикальном масштабе, и по латерали, что обуслов- лено значительными изменениями условий осадконакопления в процессе формирования сланценосной толщи как во времени, так и в пространстве. Анализ данных изменений путем построения и применения моделей формирования позволит приблизиться к решению важной практической задачи - разработке проекта пробной эксплуатации.

Рассматривая потенциальную «продуктивность» горючих сланцев, следует четко понимать, какой продукт мы хотим получить в процессе разработки месторождения. Для нефтяных компаний с целью извлечения нефти и газа наиболее продуктивными и, как следствие, более привлекательными будут пласты горючих сланцев с высоким содержанием органического вещества (OB). А для предприятий, специализирующихся на добыче рудного сырья, напротив, такие пласты будут считаться менее интересными и продуктивными. Предполагается, что для них максимальный промышленный интерес вызовут пласты с высокой зольностью и низким содержанием ОВ, в которых отмечаются высокие концентрации редких и драгоценных металлов. Исходя из сказанного, в данном сообщении под «высокой продуктивностью» горючих сланцев подразумевается высокое содержание органического вещества, высокая теплота сгорания и выход жидких УВ, а также низкая зольность.

\section{Методика}

В результате макроописания керна, литологопетрографического исследования шлифов и изучения электронно-микроскопических снимков (микрозонд JNCA-250 и электронный микроскоп Jcol 6380-LV) в составе рассматриваемой толщи выделено 11 литотипов (табл. 1). Описание шлифов производилось с использованием микроскопа AxioLab A1 POL, a их фотографирование при помощи камеры Canon $650 \mathrm{D}[3]$.

Табл. 1. Типизация литотипов

[Table 1. Typification of lithotypes]

\begin{tabular}{|c|c|c|c|c|}
\hline $\begin{array}{c}\text { № } \\
\text { литотипа } \\
\text { [No. } \\
\text { lithotype] }\end{array}$ & $\begin{array}{l}\text { Наименование литотипа } \\
\text { [Lithotype name] }\end{array}$ & $\begin{array}{c}\text { Содержание ОВ (\%) } \\
\text { [Organic matter } \\
\text { content, \%] }\end{array}$ & \begin{tabular}{|c|} 
Содержание (\%) \\
минеральной \\
составляющей \\
[Content $(\%)$ of the mineral \\
component]
\end{tabular} & $\begin{array}{c}\text { Содержание } \\
\mathrm{CaCO}_{3}(\%) \\
{\left[\mathrm{Content} \mathrm{CaCO}_{3}\right.} \\
(\%)]\end{array}$ \\
\hline 1 & Песчаники с фосфатными желваками & $0-1$ & $99-100$ & $<15$ \\
\hline 2 & Алевролиты с глинистым цементом & $2-3$ & $97-98$ & $0-15$ \\
\hline 3 & Алевролиты с кальцитовым цементом & $0-1$ & $99-100$ & $20-25$ \\
\hline 4 & $\begin{array}{l}\text { Глины без карбонатные и слабо } \\
\text { известковистые, алевритистые }\end{array}$ & $0-3$ & $97-100$ & $0-15$ \\
\hline 5 & $\begin{array}{l}\text { Глины известковистые, алевритистые и } \\
\text { алевритовые }\end{array}$ & $0-3$ & $97-100$ & $15-25$ \\
\hline 6 & Глины известковые & $0-3$ & $97-100$ & $>25$ \\
\hline 7 & Глины сапропелевые & $3-5$ & $95-97$ & $0-15$ \\
\hline 8 & Горючие сланцы известковистые & $5-30$ & $70-95$ & $5-15$ \\
\hline 9 & Горючие сланцы известковые & $30-45$ & $55-70$ & $30-40$ \\
\hline 10 & $\begin{array}{l}\text { Горючие сланцы с наиболее высоким } \\
\text { содержанием ОВ }\end{array}$ & $45-80$ & $20-55$ & $15-30$ \\
\hline 11 & Алевро-глинистые известняки & $0-1$ & $99-100$ & $75-85$ \\
\hline
\end{tabular}


В данной работе использован керновый материал по скважине № 559 Перелюбского месторождения, № 133 Коцебинского месторождения, а также с шахты месторождения Кашпир-Хвалынской площади; шлифы образцов по Перелюбскому (скважина № 559) и Коцебинскому (скважина № 133, 1038) месторождениям (всего 109 шлифов); результаты электронномикроскопической съемки кернового материала горючих сланцев скважины № 559 Перелюбского месторождения и шахты Кашпир-Хвалынского месторождения (5 образцов, 18 снимков).

\section{Литология продуктивной толщи}

Как уже отмечалась ранее, литологически сланценосная толща представлена переслаиванием глинистокарбонатных пород и горючих сланцев. Доминируют терригенные разности, реже фиксируются карбонатные литотипы, в единичных случаях выделяются породы с желваками фосфоритов. Породообразующее значение принадлежит иллиту, хлориту, смектитам, из аллотигенных минералов доминируют кварц и полевые шпаты. Органическая составляющая представлена преимущественно веществом сапропелевой природы - коллоальгинитом, также присутствуют кокколиты, фораминиферы, аммониты и двустворки $[1,3]$.

Среди горючих сланцев выделяют три основных литотипа.

Горючие сланцы известковистые, темно-серые с коричневато-зеленым оттенком. Структура органогенно-пелитовая, текстура тонкослоистая, связанная с неравномерным распределением ОВ и глинистого материала. Тип ОВ сапропелевый, также выделяется примесь гумусового вещества.

Глинистый материал смешан с коллоальгинитом и кокколитами (рис. 1), но часто образует самостоятельные микролинзовые скопления. Среди трех основных породообразующих компонентов (глинистое вещество, карбонатный материал и органическое вещество) ключевую роль играет глинистое вещество. Для этого литотипа характерна невысокая продуктивность: содержание ОВ 5 - 30\%, теплота сгорания <2000 ккал/кг, выход жидких УВ $<10 \%$, зольность 70 - 90\%.

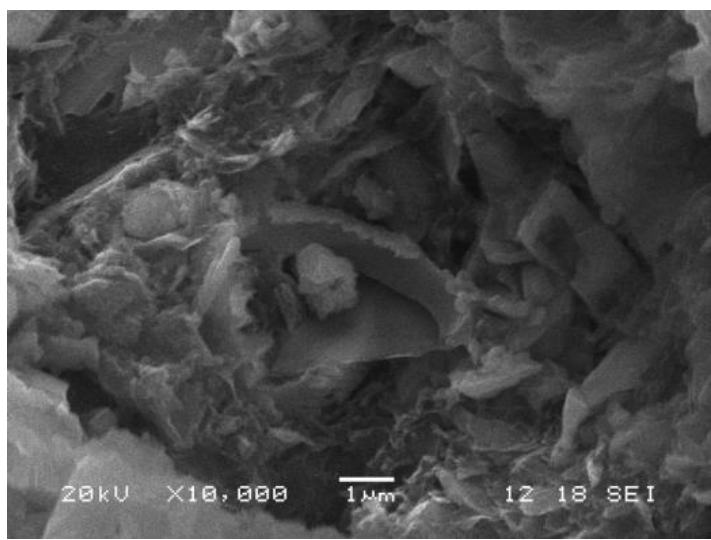

Рис. 1. Электронно-микроскопический снимок (литотип № 8). Перелюбское месторождение. Пласт № 3(2). Увели- чение $10000 x$. Кокколитофориды с низкой степенью сохранности, глинизированные. Выполнил Жабин А. В. (ВГУ).

[Fig. 1. Electronic picture (lithotype № 8). Perelubskoe deposit. Layer № 3(2). Zoom 10000x. Coccolithophora with low focalization rate, shale out. Made by Zhabin A. V.]

Горючие сланщы известковые, коричневато-серые с желтым оттенком, структура органогенно-пелитовая. Текстура тонкослоистая, обусловлена изменением оттенка окраски и насыщенностью слойков известковыми компонентами - кокколитами либо ОВ. Тип OB сапропелевый, содержание гумусового ОВ резко сокращено. Содержание органического вещества колеблется в пределах 30-45\%, представлено, преимущественно, коллоальгинитом. В микролинзах коллоальгинит смешан с крупными кокколитами средней и хорошей сохранностью (рис. 2), в меньшей мере с глинистым веществом. Кокколиты имеют максимальную величину при наличии мелких экземпляров, обладают радиально-пластинчатым строением. Содержание минеральной составляющей варьирует в пределах 55-70\%, карбонатный материал играет ведущую роль (в основном известковые кокколиты) $[1,6]$.

В данном литотипе среди трех основных породообразующих компонентов ведущее положение принадлежит карбонатам, глинистое и органическое вещество играют менее значительную роль. Горючие сланцы известковые обладают достаточно высокой продуктивностью: содержание ОВ 30-45\%, теплота сгорания 1500-3000 ккал/кг, выход жидких УВ 10$15 \%$, зольность $50-70 \%$.

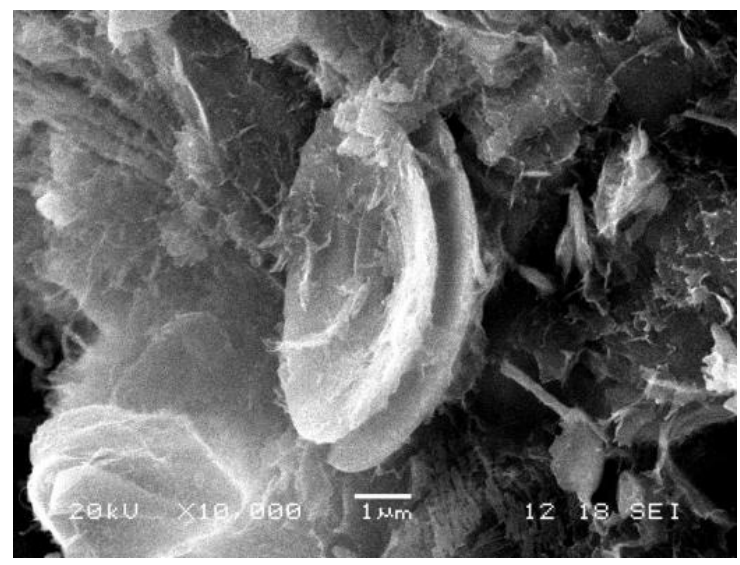

Рис. 2. Электронномикроскопический снимок; литотип № 9. Кашпир-Хвалынское месторождение; пласт № 2/2. Увеличение $10000 x$. Кокколитофориды со средней и высокой степенью сохранности, слабо глинизированные. Выполнил Жабин А. В.

[Fig. 2. Electronic picture (lithotype № 9). KashpirHvalinskoe deposit. Layer № 2(2). Zoom 10000x. Coccolithophora with medium focalization rate, low shale out. Made by Zhabin A. V.]

Рассматриваемый литотип менее распространен, однако, обладая высоким качеством, представляет больший промышленный интерес в сравнении с 
горючими сланцами известковистыми.

Горючие сланиьы с наиболее высоким содержанием $O B$ от желтовато-коричневых до светло-коричневых, структура органогенно-пелитовая. Текстура массивная, отражает равномерное распределение ОВ в породе. Тип OB сапропелевый, содержание достигает максимальных значений, по сравнению с другими литотипами, представлен коллоальгинитом и талломоальгинитом. Коллоальгинит светло-желтый прозрачный, образует крупные и мелкие сливащиеся микролинзы, форма которых нередко нарушена разрастающимися кристаллами кальцита. Степень окисленности низкая. Кокколиты хорошей сохранности, не глинизированы, рассеяны в массе коллоальгинита (рис. 3), ориентированы беспорядочно, самостоятельные микролинзовые скопления образуют редко, часто замещены кристаллами кальцита. Минеральная составляющая незначительная, варьирует в пределах 20 $55 \%[1,6]$.

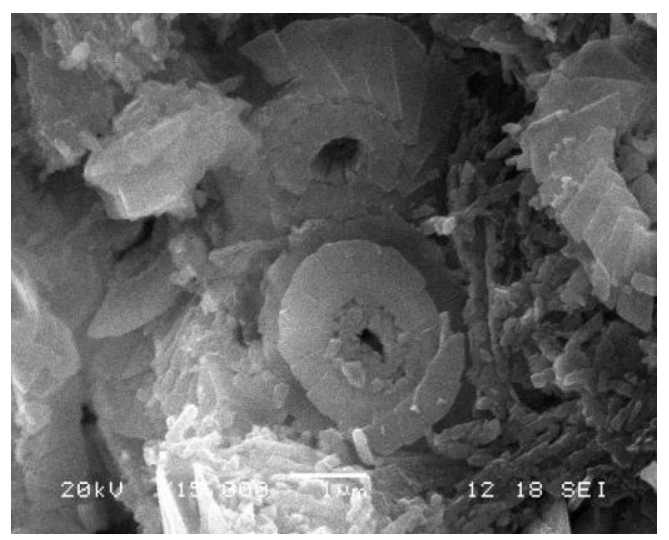

Рис. 3. Электронно-микроскопический снимок; литотип №10. Кашпир-Хвалынское месторождение. Пласт № $2 / 3$. Увеличение 15000x. Кокколитофориды с высокой степенью сохранности, не глинизированные. Выполнил Жабин А. В.

[Fig. 3. Electronic picture (lithotype № 10). KashpirHvalinskoe deposit. Layer № 2(3). Zoom 10000x. Coccolithophora with high focalization rate, none shale out. Made by Zhabin A. V.]

Среди трех основных породообразующих компонентов данного литотипа ключевая роль переходит к OB, глинистое вещество и карбонатный материал присутствуют в меньших количествах. Высокое содержанием ОВ в горючих сланцах рассматриваемого типа обеспечивает для них самую высокую продуктивность: содержание ОВ 45-80\% (значения свыше $60 \%$ установлены в единичных случаях), теплота сгорания превышает 3000 ккал/кг, выход жидких УВ выше 15\%, зольность колеблется от 40 до $65 \%$. Несмотря на наименьшее распространение литотипа в сланценосной толще, он относится к группе качественного сырья.

\section{Обсуждение результатов}

Согласно данным предыдущих исследований $[1,7$, 8], формирование рассматриваемой сланценосной толщи приурочено к палеопроливу, который соединял Тетический бассейн с Арктическим, глубина достигла 100 метров, а в придонной части периодически возникали аноксические условия.

Юдович Я. Э. [9] указывает на три основных фактора формирования горючих и черных сланцев: $\mathbf{S}$ (скорость седиментации); $\mathbf{P}$ (величина первичной биопродукции); $\mathbf{F}$ (степень фоссилизации $\mathrm{OB}$ ). Предполагается, что периодам формирования каждого выше рассмотренного литотипа отвечают условия с разной степенью влияния данных факторов.

Рассматривая фактор S, в первую очередь необходимо учитывать объем поступления терригенного материала с источников сноса и сопоставление этой величины с объемом морского планктоногенного органического вещества в конечный водоем стока (КВC). Увеличение привноса терригенного материала влечет за собой уменьшение содержания органического вещества на единицу объема породы и снижение качества горючего сланца. Данный параметр прекрасно коррелируется с зольностью горючих сланцев, увеличение которой указывает на рост поступления терригенного материала из источников сноса. В предыдущей работе, анализируя карты зольности Коцебинского месторождения [10], мы отметили отсутствие на них изолированных скважин с резким ростом зольности. Увеличение зольности приурочено к участкам, расположенным по периферии месторождения в виде локальных удаленных зон, которые протягиваются вглубь месторождения, отражая направления поступления терригенного материала из источников сноса.

В горючих сланцах с высоким содержанием ОВ (Перелюбское, Коцебинское месторождения, пласт № 1) содержание основных породообразующих окислов $\left(\mathrm{SiO}_{2}\right.$ и $\left.\mathrm{Al}_{2} \mathrm{O}_{3}\right)$, и обломочного кварца почти в два раза снижается по сравнению с горючими сланцами известковистыми (пласт № 2 на тех же месторождениях), что также указывает на колебания поступления терригенного материала. Дополнительным индикатором изменения объема терригенного материала, поступающего с водосборных площадей, служит родовой состав фораминифер. В периоды формирования ГС с высоким содержанием ОВ отмечается доминирование секреционных форм, что указывает на недостаток поступления терригенного материала и, как следствие, извлечение организмами $\mathrm{CaCO}_{3}$ из воды для формирования скелета. Напротив, в периоды формирования горючих сланцев известко-вистых отмечается увеличение роли аглютинирующих форм, т.е. в результате увеличения поступления объемов терригенного материала организмы извлекали необходимые компоненты из воды и использовали их для формирования раковин.

Биопродуктивность бассейна (фактор Р) зависела от нескольких факторов. В начальный этап сланценакопления морской бассейн был относительно узким, и в результате частых эвстатических колебаний происходила мобилизация значительного объема биофильных элементов с суши, которые поступали в 
конечный водоем стока, тем самым поддерживая высокую биопродуктивность [7, 8, 11, 12]. Применительно к нашему объекту данное явление нашло отражение в процессе формирования нижнего и среднего сланценосного горизонта, которые выделяются только на Перелюбском и Озинковском месторождениях. Здесь в начале волжского века осадконакопление происходило в узких впадинах меридионального простирания с незначительной площадью сланценакопления. Это предположение подтверждается локальным распространением нижних сланценосных горизонтов (пласты №7, 8, 9), для которых характерна значительная примесь гумусового вещества, отмечается низкий водородный индекс и высокая степень окисления органического вещества $[4,5]$.

Также высокая биопродуктивность в данный период поддерживалась за счет высоких палеотемператур и высоких объемов углекислого газа, которые активно усваивались фито- и наннопланктоном [13]. Одной из вероятных причин значительного увеличения объема углекислого газа является вулканизм. Первые следы пирокластики в зоне dorsoplanites panderi были отмечены еще в 1967 году в работах Ренгартена и Кузнецовой [14]. В дальнейшем многие исследователи отмечали как фрагменты вулканического материала в породах [1], так и следы камуфлированной пирокластики $[3,15]$. Кроме того, в последних работах Панченко И. В., Рогова М. А. [16] на территории Западной Сибири детально изучены прослои измененных пепловых туфов и туффитов в пограничных отложениях юры и мела. Источником такой масштабной вулканической деятельности могли стать вулканы Большого Кавказа, так как в Кавказской ветви Мезотетиса на протяжении всего мезозоя существовали условия активной континентальной окраины, к которой была приурочена активная цепь палеовулканизма с четырьмя этапами магматической активности - раннеюрским, среднеюрским, позднеюрско-раннемеловым и позднемеловым. Зона максимальной геодинамической активности прослеживалась вдоль бортов флишевого трога Большого Кавказа и образовывала протяженный вулканогенный пояс, в пределах которого формировались эффузивноинтрузивные комплексы [3].

Степень фоссилизации органики (фактор F) характеризует степень сохранения органического вещества и его объем, который переходит в ископаемое состояние. Чем выше степень фоссилизации органического вещества, тем выше продуктивность горючего сланца. Как уже отмечалось ранее, периодам формирования наиболее высоко качественных ГС отвечают обстановки дефицита кислорода и сероводородного заражения в придонной части бассейна, т.е. развитие придонной аноксии, что напрямую влияло на степень фоссилизации ОВ. Наличие сероводородного заражения позволяло активно развиваться «природной вулканизации», подробно описанной в работе Бушнева Д. А. [17]. Природная вулканизация является одним из основных механизмов, приводящих к эффективному захоронению в осадке исходного органического вещества в субаквальных условиях. Суть процесса состоит в том, что содержащиеся в наддонных и поровых водах соединения восстановленной серы $\left(\mathrm{H}_{2} \mathrm{~S}\right.$, HS-, HSn-) взаимодействуют с функциональными группами компонентов исходного органического вещества (в мягких условиях природного диагенеза), а полученные производные оказываются более устойчивыми к факторам деградации, чем первичные биомолекулы.

Развитие аноксических условий было обусловлено следующими факторами: спокойной гидродинамической обстановкой, стратификацией водной толщи, большим объемом органического вещества в придонной части бассейна и, как следствие, развитием процессов сульфатредукции $[1,3,6,11,18$, 19, 20, 21].

Наличие придонной аноксии в процессе формирования сланценосной толщи доказывается следующими фактами. Все ГС рассматриваемого объекта являются высокосернистыми (преимущественно органическая сера), среднее содержание варьирует от 3 до 5\%, при пиковых значения 7 и даже $10 \%$. Основным акцессорным минералом является пирит, значения которого увеличиваются к наиболее продуктивным разностям горючих сланцев. На плоскостях горючих сланцев выделяются массовые заморы юных и зрелых особей аммонитов, что свидетельствует о резком ухудшении палеоэкологической обстановки, также отмечается сокращение фораминиферового числа от менее продуктивных горючих сланцев (горючие сланцы известковистые) к более продуктивным (горючие сланцы с высоким содержанием ОВ) [3]. На основании анализа основных геохимических индикаторов - молибден/марганцевое отношение [22] и $\mathrm{DOP}_{\mathrm{R}}$ (степень пиритизации железа) [23], было установлено, что наиболее продуктивные разности горючих сланцев находятся в диапазоне, отвечающем развитию аноксических обстановок (рис. 4) [3].

Исходя из изложенного, модели формирования литотипов ГС выглядят следующим образом.

Горючие сланцы известковистые. Для них характерны (пласт №2 ГС Коцебинского месторождения) высокие содержания основных породообразующих окислов: $\mathrm{SiO}_{2}-36.31 \%, \mathrm{Al}_{2} \mathrm{O}_{3}-12.6 \%$; содержание обломочного кварца варьирует от 3 до 5\%. Как следствие, средняя зольность сырья колеблется от 70 до $80 \%$. В микрофаунистических палеоценозах важная роль принадлежит аглютинирующим формам [3]. Следовательно, в процессе формирования данного литотипа важную роль играл фактор $\mathbf{S}$, снижавший концентрацию ОВ на единицу объема в породе.

Для оценки влияния фактора $\mathbf{P}$ рассмотрим отношение $\mathrm{P} / \mathrm{Ti}$ как одного из возможных геохимических индикаторов палеопродуктивности [24]. Величина этого отношения для рассматриваемого пласта составляет 0.8 , что свидетельствует, вероятно, о высокой биопродуктивности палеобассейна. 
Диапазон 0,03 - 0,18, отвечающий аноксическим обстановкам

[anoxic events range - $0,03-0,18$ ]
Диапазон 0,55 - 0,93, отвечающий аноксическим обстановкам [anoxic events range - 0,55 - 0,93]

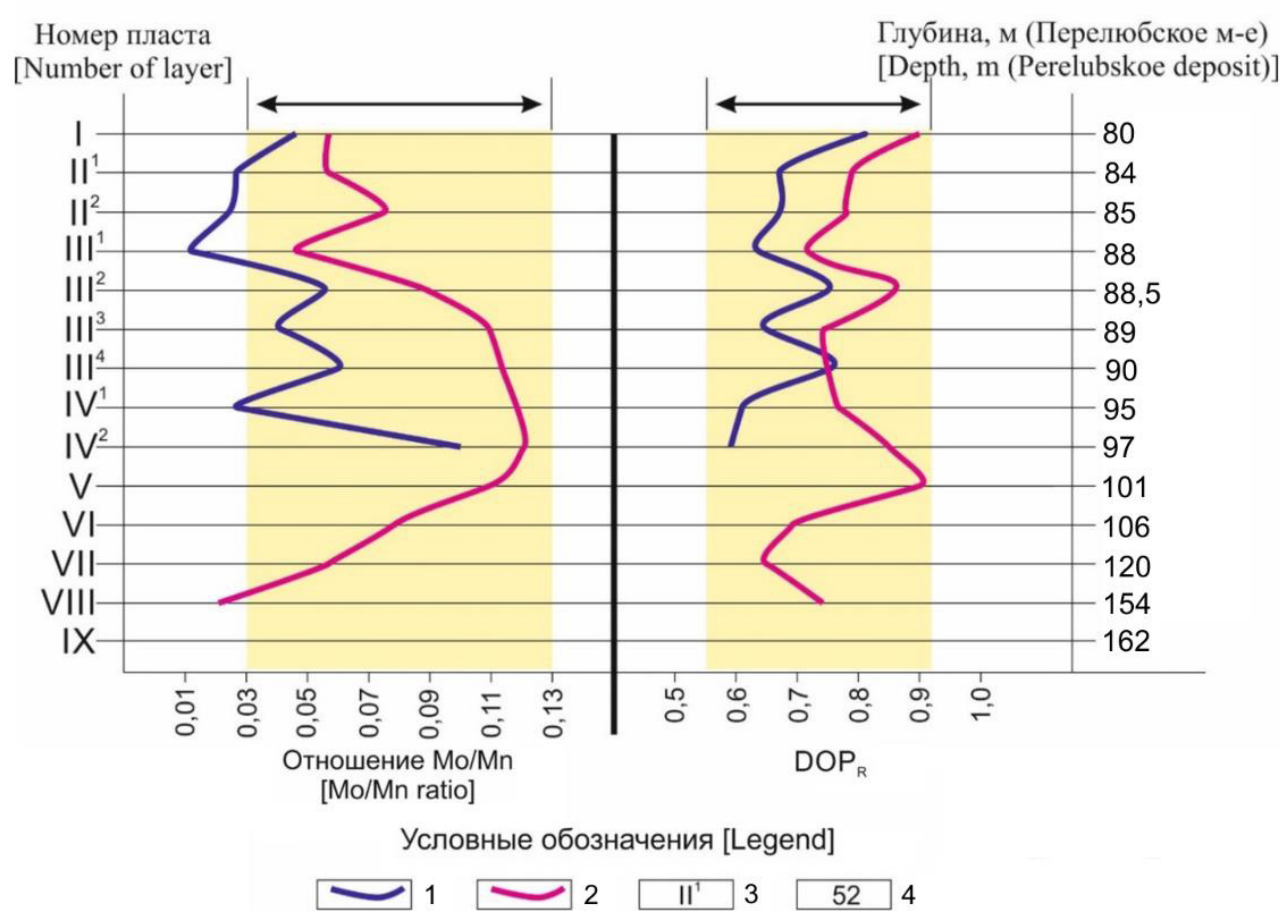

Рис. 4. Геохимические индикаторы развития аноксических обстановок на Перелюбском и Коцебинском месторождении. Условные обозначения: 1 - Коцебинское месторождение; 2 - Перелюбское месторождение; 3 - номер пласта, первая цифра номер пласта, вторая номер пачки; 4 - глубина залегания пласта горючего сланца на Перелюбском месторождении, м.

[Fig. 4. Geochemical indicators of development anoxic events based on Perelubskoe and Kotsebinskoe deposits: 1 - Kotsebinskoe deposit; 2 - Perelubskoe deposit; 3 - Number of layer, first symbol number of layer, second number of unit; 4 - layers depth on Perelubskoe deposit.]

Для оценки роли фактора $\mathbf{F}$ предпочтительно рассматривать геохимический индикатор $\mathrm{Mo} / \mathrm{Mn}$ (рис. 4), величина которого для второго продуктивного пласта выходит из диапазона, отвечающего аноксическим условиям. Вероятнее всего, условия осадконакопления были близки к глеевой обстановке, возможно даже с периодическим нормальным газовым режимом, что способствовало окислению ОВ. На это указывают невысокие средние содержания серы 3\% (по сравнению с другими пластами горючих сланцев), высокие значения фораминиферового числа и наличие окисленного ОВ с не высокой степенью сохранности [3]. Поэтому фактор $\mathbf{F}$ играл незначительную роль в процессе формирования данного литотипа.

Совместное влияние всех трех факторов обусловило низкую продуктивность анализируемого литотипа (рис. 5).

Горючие сланияы с наиболее высоким содержанием $O B$ (пласт 1 Коцебинского месторождения) представляют собой наиболее качественное сырье ГС. Для них характерны самые низкие значения основных породообразующих окислов: $\mathrm{SiO}_{2}-15.25 \% ; \mathrm{Al}_{2} \mathrm{O}_{3}-3.84 \%$, невысокие содержания обломочного кварца (1.5\%) и низкая зольность (40-50\%) [3], что указывает на незначительную роль фактора $\mathbf{S}$ при формировании данного литотипа. Роль аглютинирующих форм значительно снижается, уступая секреционным формам, что также указывает на дефицит терригенного материала в конечном водоеме стока.

Значение фактора $\mathbf{P}$ для данного литотипа играет важную роль и обеспечивает значительное поступление ОВ в придонную часть бассейна. Доказательством является величина отношения геохимического индикатора $\mathrm{P} / \mathrm{Ti}$, которая достигает максимальных значений 2.35, указывая на возможный «взрыв» биопродуктивности палеобассейна.

Наиболее важное значение при формировании рассматриваемого литотипа принадлежало фактору $\mathbf{F}$. Максимальные значения содержания серы, широкое развитие пирита, наличие заморов молоди аммонитов и низкое значение фораминиферового числа - все это указывает на развитие придонной аноксии и высокую степень фоссилизации ОВ. Именно здесь отмечается наиболее высокая степень сохранности ОВ. Также дополнительным подтверждением значимости фактора $\mathbf{F}$ служат геохимические индикаторы $\mathrm{Mo} / \mathrm{Mn}$, $\mathrm{DOP}_{\mathrm{R}}$, значения которых, полученные для первого продуктивного пласта, отвечают развитию придонной аноксии [3].

Высокая степень фоссилизации ОВ, низкий объем поступления терригенного материала и «взрывной» рост биопродуктивности палеобассейна послужили причиной формирования самого перспективного для разработки литотипа ГС (рис. 6). 


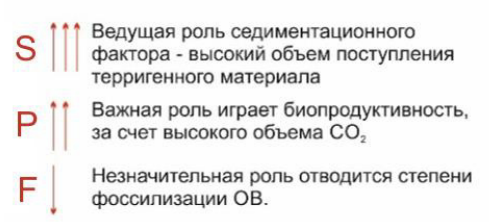

[Main role playing sedimentory factor - high inflow rate of terrigenic material]

[Important role of basin bioproduction - high $\mathrm{CO}_{2}$ volume]

[Small role of fossilization organic matter rate]
Условные обозначения

[Legend]

$\therefore \because \because 1$

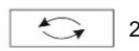

こニニ 3

$\mathrm{IO}_{2} \quad 4$

$\mathrm{H}_{2} \mathrm{~S}$

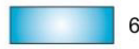

$0 \div \% 8$

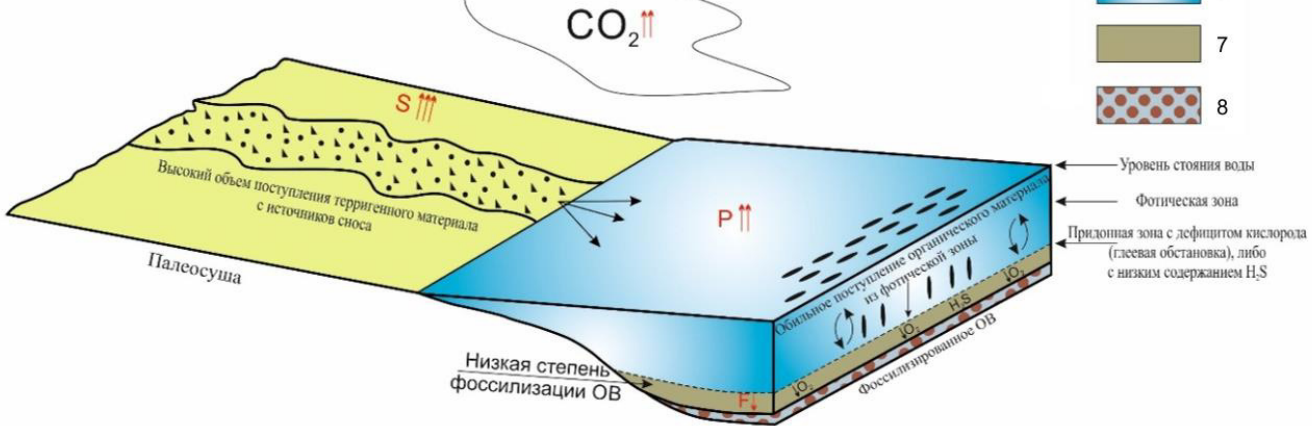

Рис. 5. Модели формирования горючих сланцев известковистых. Условные обозначения: 1 - поступление терригенного материала с источников снова; 2 - рециклинг; 3 - автохтонное ОВ; 4 - активный расход кислорода; 5 - образование сероводорода; 6 - морская толща; 7 - придонная зона с дефицитом кислорода; 8 - первичный осадок.

[Fig. 5. Accumulation model of low calcareous oil shales. Legend: 1 - terrigenic material inflow from source area; 2 - recycling; 3 autochthonous organic matter; 4 - active oxygen flowrate; $5-\mathrm{H}_{2} \mathrm{~S}$ formation; 6 - water column; 7 - bottom zone with low oxygen rate; $8-$ sediments.]

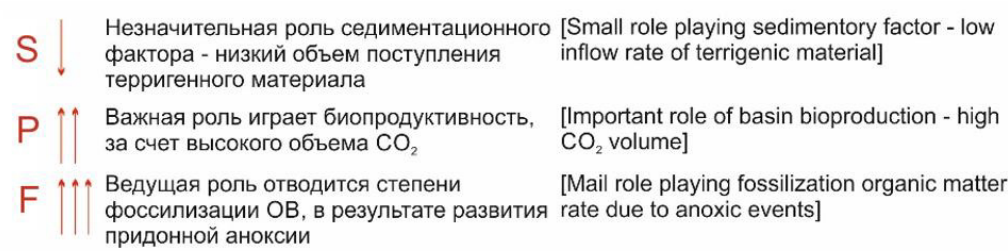
придонной аноксии
Условные обозначения

[Legend]

$\because \because \because 1$

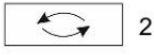

こニン 3

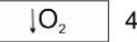

$\mathrm{H}_{2} \mathrm{~S} 5$

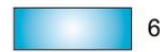

$\because \because 8$

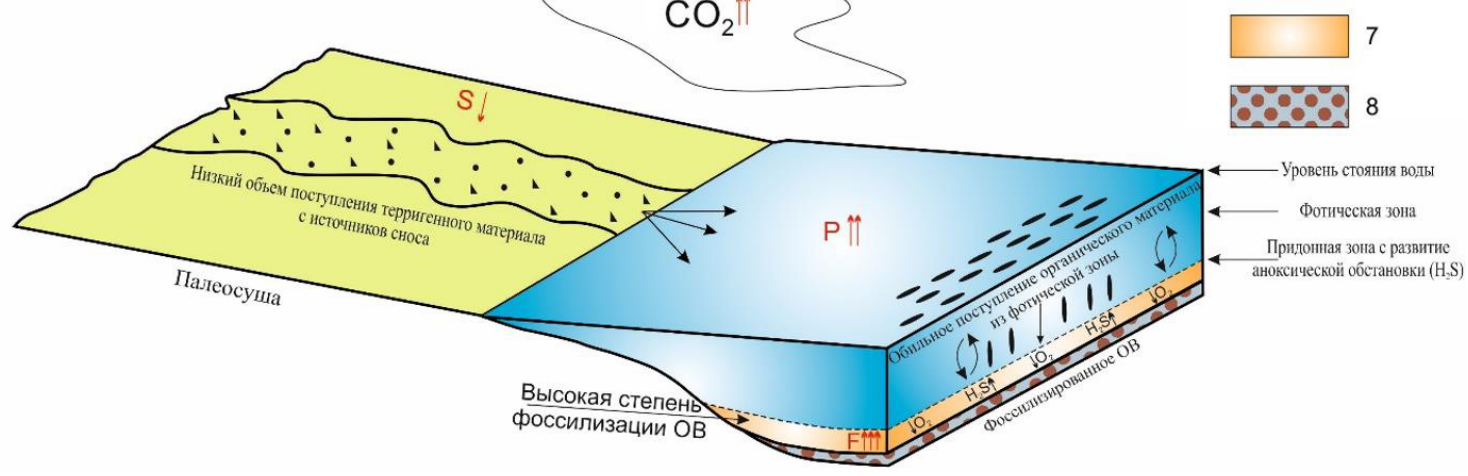

Рис. 6. Модели формирования горючих сланцев с наиболее высоким содержанием ОВ. Условные обозначения: 1 - поступление терригенного материала с источников снова; 2 - рециклинг; 3 - автохтонное ОВ; 4 - активный расход кислорода; 5 - образование сероводорода; 6 - морская толща; 7 - придонная зона с дефицитом кислорода; 8 - первичный осадок.

[Fig. 6. Accumulation model of oil shales enrich with organic matter. Legend: 1 - terrigenic material inflow from source area; $2-$ recycling; 3 - autochthonous organic matter; 4 - active oxygen flowrate; $5-\mathrm{H}_{2} \mathrm{~S}$ formation; 6 - water column; 7 - bottom zone with low oxygen rate; $\ddot{e}$-sediments.] 


\section{Заключение}

Таким образом, каждый из рассмотренных факторов сыграл важную роль в формировании рассматриваемых литотипов горючих сланцев, однако только особенности их совместного влияния привели к образованию высокопродуктивных и низкопродуктивных горючих сланцев. Ключевую роль при формировании горючих сланцев с наиболее высоким содержанием ОВ сыграл фактор F, а именно высокая степень фоссилизации ОВ. При формировании горючих сланцев известковистых ведущая роль отводилась фактору $\mathrm{S}$, связанному с высоким объемом поступления терригенного материала с источников сноса. На протяжении формирования двух рассматриваемых литотипов не маловажную роль играл также фактор Р, именно высокая биопродуктивность обеспечивала большого объем поступления органического материала в придонную часть бассейна.

В дальнейшем применение данных моделей позволит более достоверно оценивать качество горючих сланцев уже при бурении поисковых и разведочных скважин.

Конфликт интересов: Авторы декларируют отсутствие явных и потенциальных конфликтов интересов, связанных с публикацией настоящей статьи.

\section{ЛИТЕРАТУРА}

1. Букина Т. Ф. Седиментогенез и ранний литогенез верхнеюрских сланценосных отложений центральной части Волжского бассейна. Саратов : изд-во Саратовского ун-та, 2013. $128 \mathrm{c}$.

2. Рогов М. А. Аммониты и инфразональное расчленение зоны Dorsoplanites Panderi (Волжский ярус, верхняя юра) Европейской части России // Доклады академии наук. 2013. T. 431, № 4. C. 435-440.

3. Илясов В. С. Условия формирования верхнеюрских горючих сланцев Волжского бассейна на примере месторождений Саратовского Поволжья: дисс. ... канд. геол.-мин. наук: (25.00.06). Москва, 2020. 237 с.

4. Илясов В. С., Староверов В. Н., Воробьева Е. В., Решетников М. В. Геохимическая характеристика горючих сланцев волжской сланценосной толщи в связи с прогнозированием промышленных концентраций рения // Известия Сарат. ун-та. Нов. сер. Сер. Науки о Земле. 2017. Т. 17, вып. 3. С. 165-170.

5. Илясов В. С., Староверов В. Н., Воробьева Е. В. О влиянии литологического состава горючих сланцев Волжского сланценосного бассейна на их технологические параметры // Приборы и системы разведочной геофизики. 2016. № 58. C. 92-102.

6. Барышникова В. Н., Букина Т. Ф., Еремин В. Н., Иванов А. В., Кулева Г. В., Троицкая Е. А., Яночкина З. А. Разрез верхнеюрских сланценосных отложений Волжского бассейна (зона Dorsoplanites panderi). Саратов: Научная книга, 2004. $110 \mathrm{c}$.

7. Гаврилов Ю. О., Щепетова Е. В., Рогов М. А., Щербинина Е.А. Седиментология, геохимия и биота Волжских углеродистых отложений средней части среднерусского моря (Костромская область) // Литология и полезные ископаемые. 2008. № 4. С. 396-424.

8. Щепетова Е. В. Седиментология и геохимия углеродистых толщ верхней юры и нижнего мела Русской плиты: автореф. дисс. ... канд. геол.-мин. Наук : (25.00.06). Москва,
2011. $24 \mathrm{c}$.

9. Юдович Я. Э., Кетрис М. П. Геохимия черных сланцев. Л.: Наука, 1988. 272 с.

10. Илясов В. С., Староверов В. Н., Вахрамеев П. А. Построение и анализ продуктивной модели Коцебинского месторождения в связи с перспективами разработки горючих сланцев // Международный научный журнал «Путь науки». 2018. № 1(47). С. 73-87.

11. Гаврилов Ю. О. О возможных причинах накопления отложений, обогащенных органическим веществом, в связи с эвстатическими колебаниями уровня моря // Проблемы эволюции биосферы. 1994. С. 305-311.

12. Гаврилов Ю. О., Копаевич Л. Ф. О геохимических, биохимических и биотических следствиях эвстатических колебаний // Стратиграфия. Геологическая коррелящия. 1996. Т. 4. № 4. C. 3-14.

13. Price G. D. Rogov M. A. An isotopic appraisal of the Late Jurassic greenhouse phase in the Russian Platform // Palaeogeography, Palaeoclimatology, Palaeoecology. 2009. V. 273. P. 41-49.

14. Ренгартен И. В., Кузнецова К. И. Пирокластический материал в позднеюрских осадках Русской платформы // Докл. АН СССР. 1967. Т. 173. № 6. С. 1422-1425.

15. Зорина С. О., Афанасьева Н. И., Жабин А. В. Следы пирокластики в сантон-кампанских отложениях разреза «Вишневое» (Среднее Поволжье) // Литосфера. 2012. № 3. C. $3-13$.

16. Панченко И.В., Соболев И. Д., Рогов М. А., Латышев А. В. Вулканические туфы и туффиты в пограничных ярусах отложений юры и мела (волжско-рязанские ярусы) Западной Сибири // Литология и полезные ископаемые. 2021. № 2. C. 1-40. DOI: 10.31857/S0024497X21020051

17. Бушнев Д. А. Геохимия органического вещества углеродистых толщ Восточно-Европейской платформы: дисс. ... дра геолого-минералогических наук: (25.00.09; 25.00.12). Сыктывкар, 2007. 255 с.

18. Гаврилов Ю. О., Щепетова, Е. В., Барабошкин, Е. Ю., Щербинина, Е. А. Аноксический раннемеловой бассейн русской плиты: седиментология и геохимия // Литология $u$ полезные ископаемые. 2002. № 4. С. 359-380.

19. Зорина С. О. Эвстатические и геодинамические особенности формирования средне- и верхнеюрских отложений на востоке Русской плиты // Юрская система России: проблемы стратиграфии и палеогеографии. Второе Всероссийское совещание: научные материалы. Ярославль: ЯГПУ, 2007. С. 87-89.

20. Илясов В. С., Староверов В. Н. Роль седиментационного фактора в формировании сланценосной толщи средневолжского подъяруса на юго-востоке Волго-Уральской антеклизы // Инновации в разведке и разработке нефтяных и газовых месторождений. 2016. Т. 1. С. 176-299.

21. Илясов В. С., Староверов В. Н. Модели формирования пластов горючих сланцев Волжского бассейна на примере месторождений Саратовского Поволжья // Недра Поволжья и Прикаспия. 2018. № 94. С. 3-13.

22. Холодов В. Н. Геохимия осадочного процесса Москва: ПК ГЕОС, 2006. 608 с.

23. Юдович Я. Э., Кетрис М. П. Геохимические индикаторы литогенеза (литологическая геохимия). Сыктывкар: Геопринт, 2011. $742 \mathrm{c}$.

24. Algeo T. J., Kuwahara K., Sano H., Bates S., Lyons T., Elswick E., Hinnov L., Ellwood B., Moser J., Maynard J.B. Spatial variation in sediment fluxes, redox conditions, and productivity in the Permian-Triassic Panthalassic Ocean // Palaeogeography, Palaeoclimatology, Palaeoecology. 2011. Vol. 111. P. $65-83$ 


\title{
Upper Jurassic oil shale of the Volga basin: lithotypes, formation models and producibility
}

\author{
¿ 2021 V. S. Ilyasov ${ }^{1 \bowtie}$, V. N. Staroverov ${ }^{2}$ \\ ${ }^{1}$ LLC «NewTech Services», 31 G Shabolovka Str., 115162 Moscow, Russian Federation \\ ${ }^{2} J S C$ «NVNIIGG», st. Moskovskaya 70, 413503 Saratov, Russian Federation
}

\begin{abstract}
Introduction: The producibility of oil shale from the Kotsebinskoe and Perelyubskoe fields varies greatly, both vertically and laterally. This article is devoted to the study of the influence of the variability of formation conditions on the producibility of oil shale in the Volga basin.

Methodology: In this study, the following methods were used: macro description of core, lithologic and petrographic study of cross-sections, and the study of electron microscopic images. When analysing the conditions for oil shale formation, we used the material obtained during the prospecting and appraisal activities and exploration at the Kotsebinskoe and Perelyubskoe fields.

Results and discussion: Based on the study of the main lithotypes of oil shale of the Kotsebinskoe and Perelyubskoe fields, we determined the processes influencing the producibility of oil shale, such as the volume of terrigenous material inflow, the bioproduction of the paleobasin, and the degree of fossilisation of organic matter (OM).

Conclusions: It was determined that the low producibility of oil shale is due to a high intensity of the terrigenous material inflow from the migration area, and a low degree of OM fossilisation. In return, the increase in the producibility of oil shale is associated with a low inflow of terrigenous material and a high degree of OM fossilisation. For two lithotypes, the high bioproduction of the paleobasin is also supposed. The obtained data allowed us to build and study the probable "idealised" models of oil shale formation. In the future, these data can be used to remodel the conditions for the formation of each productive layer of oil shale.

Keywords: oil shale, Volga basin, producibility, Kotsebinskoe field, anoxic conditions, volcanism.

For citation: Ilyasov V. S., Staroverov V. N. Upper Jurassic oil shale of the Volga basin: lithotypes, formation models and producibility. Vestnik Voronezhskogo gosudarstvennogo universiteta. Seriya: Geologiya - Proceedings of Voronezh State University. Series: Geology. 2021, no. 1, pp. 26-35. DOI: https://doi.org/10.17308/geology.2021.1/3335.

Conflict of interests: The authors declare the absence of obvious and potential conflicts of interest related to the publication of this article.
\end{abstract}

\section{REFERENCE}

1. Bukina T. F. Sedimentogenez $i$ rannii litogenez verkhneyurskikh slantsenosnykh otlozhenii tsentral'noi chasti Volzhskogo basseina [Sedimentogenesis and early lithogenesis of upper Jurassic oil shales deposits of Volzhskii basin central part]. Saratov. Publishing office of Saratov University, 2013. 128 p. (In Russ.)

2. Rogov M. A. Ammonity i infrazonal'noe raschlenenie zony Dorsoplanites Panderi (Volzhskii yarus, verkhnyaya yura) Evro peiskoi chasti Rossii [Ammoniates and infrazoneal dismemberment Dorsoplanites Panderi zone (Voljskyi strata, upper Jurassic) European part of Russia]. Doklady akademii nauk. - Reports of the Academy of Sciences, 2013, vol. 431, no. 4, pp. 435-440. (In Russ.)

3. Ilyasov V.S. Usloviya formirovaniya verkhneyurskikh goryuchikh slantsev Volzhskogo basseina na primere mestorozhdenii Saratovskogo Povolzh'ya. Diss. kand. geol.-min. nauk [Upper Jurassic oil shales accumulation conditions in Volzhskii Basin based on Saratov development in Volga region. $\mathrm{PhD}$ in geol.-min. diss]. Mocsoe, 2020. 237 p. (In Russ.)

The content is available under Creative Commons Attribution 4.0 License.

\footnotetext{
${ }^{\bowtie}$ Valeryi S. Ilyasov, e-mail: 230989@list.ru
} 
4. Ilyasov V. S., Staroverov V. N., Vorobieva E. V., Reshetnikov M.V. Geokhimicheskaya kharakteristika goryuchikh slantsev volzhskoi slantsenosnoi tolshchi v svyazi s prognozirovaniem promyshlennykh kontsentratsii reniya [Geochemical Characteristics of Oil Shales in the Volzhskii Basin and Productive Forecast of Rhenium Commercial Concentrations]. Izvestiya Sarat. un-ta. Nov. ser. Ser. Nauki o Zemle - Izv. Saratov Univ. (N.S.), Ser. Earth Sciences, 2017, vol. 17, no. 3, pp. 165-170. (In Russ.)

5. Ilyasov V.S., Staroverov V.N., Vorobieva E.V. O vliyanii litologicheskogo sostava goryuchikh slantsev Volzhskogo slantsenosnogo basseina na ikh tekhnologicheskie parametry [Volzhskii Basin oil shales lithological composition impact on their technical properties] Pribory $i$ sistemy razvedochnoi geofiziki-Device and system of exploring geophys. 2016, no. 58, pp. 92-102. (In Russ.)

6. Kuleva G. V., Yanochkina Z. A., Bukina T. F. Razrez verkhneyurskikh slantsenosnykh otlozhenii Volzhskogo basseina (zona Dorsoplanites panderi) [Cross-cutting upper Jurassic oil shale zone of Volzhskii Basin (Dorsoplanites panderi zone)] edit by Z. A. Yanochkina, A. V. Ivanova. Saratov, Nauchnaya kniga publ., 2004. 110 p. (In Russ.)

7. Gavrilov U. O. Shepetova E. V., Rogov M. A., Sherbinina E. A. Sedimentologiya, geokhimiya i biota Volzhskikh uglerodistykh otlozhenii srednei chasti srednerusskogo morya (Kostromskaya oblast') [Upper Jurassic and lower Cretaceous carbon deposits of Russian Plate - sedimentology, geochemistry and biota]. Litologiya poleznye iskopaemye - Lithology and mineral resources, 2008, no. 4, pp. 396-424. (In Russ.)

8. Shepetova E. V. Sedimentologiya, geokhimiya i biota Volzhskikh uglerodistykh otlozhenii srednei chasti srednerusskogo morya (Kostromskaya oblast'). Avtoref. diss. kand. geol.-min. nauk [Jurassic and lower Cretaceous carbon deposits of Russian Plate - sedimentology, geochemistry. Extended abstract of diss. PhD in geol.-min.] Moscow, 2011. 24 p. (In Russ.)

9. Yudovich Ya. E., Ketris M. P. Geokhimiya chernykh slantsev [Black shales geochemistry]. Leningrad, Nauka publ., 1988. 272 p. (In Russ.) 10. Ilyasov V. S., Staroverov V. N., Vakhrameyev P. A. Postroenie analiz produktivnoi modeli Kotsebinskogo mestorozhdeniya v svyazi s perspektivami razrabotki goryuchikh slantsev [Generation and analysis of Kotsebinskoe development productive model in relation to oil shales perspective exploration] Mezhdunarodnyi nauchnyi zhurnal "Put' nauki» - International scientific journal "The Way of Science". 2018, no. 1(47), pp. 73-87. (In Russ.)

11. Gavrilov Yu. O. O vozmozhnykh prichinakh nakopleniya otlozhenii, obogashchennykh organicheskim veshchestvom, v svyazi s evstaticheskimi kolebaniyami urovnya moray [Probably causes of sediments accumulation enrich with organic matter and connection with eustatic movements]. Problemy evolyutsii biosfery - Biosphere evolution problem, 1994, pp. 305-311. (In Russ.)

12. Gavrilov Yu. O., Kopaevich L.F. O geokhimicheskikh, biokhimicheskikh i bioticheskikh sledstviyakh evstaticheskikh kolebanii [Geochemical, biochemical and biotic causes from eustatic movements]. Stratigrafiya. Geologicheskaya korrelyatsiya - Stratigraphy. Geological correlation, 1996, vol. 4, no. 4, pp. 3-14. (In Russ.)

13. Price G. D., Rogov M. A. An isotopic appraisal of the Late Jurassic greenhouse phase in the Russian Platform. Palaeogeography, Palaeoclimatology, Palaeoecology, 2009, vol. 273, pp. 41-49.
14. Rengarten I. V., Kyznecova K. I. Piroklasticheskii material v pozdneyurskikh osadkakh Russkoi platform [Pyroclastic material in upper Jurassic sediments in Russian Plate]. Dokl. AN SSSR - Report AN USSR, 1967, vol. 173, no. 6, pp. 1422-1425. (In Russ.)

15. Zorina S. O., Afanasjeva N. I., Zhabin A. V. Sledy piroklastiki v santon-kampanskikh otlozheniyakh razreza «Vishnevoe» (Srednee Povolzh'e) [Traces of pyroclastics in Santonian-Campanian deposits ("Vishnevoje" section, the Middle Volga)]. Litosfera - Lithosphere, 2012, no. 3, pp. 3-13. (In Russ.)

16. Panchenko I.V., Sobolev I. D., Rogov M. A., Latyshev A. V. Volcanic Tuffs and Tuffites at the Jurassic-Cretaceous Boundary Beds (Volgian-Ryazanian Stages) of Western Siberia. Litologiya $i$ poleznye iskopaemye. - Lithology and mineral resources, 2021, no. 2, pp. 1-40. DOI: 10.31857/S0024497X21020051. (In Russ.)

17. Buhnev D. A. Geokhimiya organicheskogo veshchestva uglerodistykh tolshch Vostochno-Evropeiskoi platform. Diss. d-ra geol.min. nauk [Geochemistry of organic matter in carbon deposits of East-European platform. Doct. Diss. Syktyvkar, 2007. 255 p. (In Russ.)

18. Gavrilov Yu. O., Shepetova E. V., Baraboshkin E. U., Sherbinina E. A. Anoksicheskii rannemelovoi bassein russkoi plity: sedimentologiya i geokhimiya [Anoxia Early Cretaceous basin of Russian plate - sedimentology and geochemistry]. Litologiya $i$ poleznye iskopaemye. - Lithology and mineral resources, 2002, no. 4, pp. 359-380. (In Russ.)

19. Zorina S. O. Evstaticheskie i geodinamicheskie osobennosti formirovaniya sredne- i verkhneyurskikh otlozhenii na vostoke Russkoi plity [Eustatic and geodynamic accumulation aspects of middle and upper Jurassic deposits on east part of Russian plate]. Yurskaya sistema Rossii: problemy stratigrafii i paleogeografii. Vtoroe Vserossiiskoe soveshchanie: nauchnye materialy [Russian Jurassic system: stratigraphy and paleogeographic problem. The second Russian conference: science material] Yaroslavl, YGPU, 2007, pp. 87-89. (In Russ.)

20. Ilyasov V. S. Staroverov V. N. Rol' sedimentatsionnogo faktora v formirovanii slantsenosnoi tolshchi srednevolzhskogo pod"yarusa na yugo-vostoke Volgo-Ural'skoi anteklizy [Sedimentary factor effort in oil shales productive zone accumulation (Volgian substage) on south-east part of Volgo-Uralskaya anteclise]. Innovatsii $v$ razvedke $i$ razrabotke neftyanykh $i$ gazovykh mestorozhdenii Innovation in search and exploration oil and gas file, 2016, vol.1, pp. 176-299. (In Russ.)

21. Ilyasov V. S., Staroverov V.N. Modeli formirovaniya plastov goryuchikh slantsev Volzhskogo basseina na primere mestorozhdenii Saratovskogo Povolzh'ya [Formation models of oil shales layers (Volzhskii Basin) based on Saratov development in Volga region]. Nedra Povolzh'ya i Prikaspiya, 2018, no 94, pp. 3-13. (In Russ.)

22. Kholodov V. N. Geokhimiya osadochnogo protsessa [Geochemistry of sedimentary process]. Moscow, PK GEOS publ., 2006, 608 p. (In Russ.)

23. Yudovich Ya. E., Ketris M. P. Geokhimicheskie indikatory litogeneza (litologicheskaya geokhimiya) [Geochemical Indicators of Lithogenesis]. Syktyvkar, Geoprint publ., 2011. 742 p. (In Russ.)

24. Algeo T.J., Kuwahara K., Sano H., Bates S., Lyons T., Elswick E., Hinnov L., Ellwood B., Moser J., Maynard J.B. Spatial variation in sediment fluxes, redox conditions, and productivity in the Permian-Triassic Panthalassic Ocean. Palaeogeography, Palaeoclimatology, Palaeoecology, 2011, vol. 111, pp. 65-83.
Илясов Валерий Сергеевич - к.г.-м.н., ведущий геолог, ООО «НьюТек Сервисез», Москва, РФ, e-mail: 230989@list.ru; ORCID https://orcid.org/0000-0003-3777-4926.

Староверов Вячеслав Николаевич - д. г.-м. н., главный научный сотрудник, АО «Нижневолжский научноисследовательский институт геологии и геофизики», Саратов, РФ, e-mail: staroverovvn@gmail.com; ORCID https://orcid.org/0000-0002-8457-4989 Авторы прочитали и одобрили окончательный вариант рукописи.
Valeryi S. Ilyasov - PhD in geol.-min., Senior geologist, LLL «NewTech Services» Moscow, RF, e-mail: 230989@list.ru; ORCID https://orcid.org/0000-0003-3777-4926.

Vyacheslav N. Staroverov - PhD, Dr. habil. in Geol.-Min., Chief Researcher, JSC «NVNIIGG» Saratov, RF, e-mail: staroverovvn@gmail.com; ORCID https://orcid.org/0000-0002-8457-4989

The authors have read and approved the final manuscript. 